\title{
The Effects of Tax and Promotion on Rubber Medical Devices Export
}

\author{
(Kesan Cukai dan Promosi ke atas Eksport Peranti Perubatan Berasaskan Getah)
}

\author{
Lee Siu Ming \\ Universiti Sains Malaysia \\ Radziah Adam \\ Universiti Sains Malaysia \\ Ku' Azam Tuan Lonik \\ Universiti Sains Malaysia
}

ABSTRACT

This study examines the effects of cess and export promotion on rubber medical devices export by employing a modified gravity model. The export promotion activities include overseas office, trade missions and trade fairs. Using a balanced panel data of Malaysia, the findings show that cess reduces rubber medical devices export indicating its potential of limiting this export. The results further show that overseas office establishment increases rubber medical devices export growth. These two sets of policies, namely cess and export promotion activities are indeed intertwined and are difficult to be considered separately. In increasing global market share for rubber medical devices, Malaysia continues its export promotion efforts and cess is currently the sole funding.

Keywords: Export promotion activities; cess; rubber medical devices; export; gravity model

ABSTRAK

Kajian ini memeriksa kesan ses dan promosi eksport ke atas eksport peranti perubatan berasaskan getah menggunakan model graviti yang diubahsuai. Aktiviti promosi eksport termasuklah pejabat di luar negara, misi perdagangan dan pameran perdagangan. Menggunakan data panel seimbang Malaysia, hasil kajian mendapati bahawa ses mengurangkan eksport peranti perubatan berasaskan getah yang menunjukkan potensinya dalam mengehadkan eksport ini. Keputusan selanjutnya mendapati bahawa penubuhan pejabat di luar negara meningkatkan pertumbuhan eksport peranti perubatan berasaskan getah. Kedua-dua dasar ini iaitu ses dan aktiviti promosi eksport merupakan suatu jalinan dan sukar untuk dipisahkan. Dalam usaha meningkatkan saham pasaran global bagi peranti perubatan berasaskan getah, Malaysia meneruskan usaha promosi eksport dan ses merupakan pembiayaan tunggal.

Kata kunci: Aktiviti promosi eksport; ses; peranti perubatan berasaskan getah; eksport; model graviti

\section{INTRODUCTION}

Malaysia is the world's largest exporter of rubber medical devices (RMD), contributing to Malaysia having an uninterrupted 22 year positive trade balance, 2019 (Ministry of International Trade and Industry 2020). RMD consist of three main products: rubber gloves, sheath contraceptives, and rubber catheters. ${ }^{1}$ Data from the United Nations Commodity Trade Statistics (UN Comtrade) shows that the export of Malaysian RMD was valued at USD3.5 billion in 2013, an increase in compounded annual growth rate (CAGR) of 10.6\% from USD0.3 billion in 1989.

The factors including the (1) increase in the awareness and education of infection control and prevention, and (2) increase in healthcare demands are linked to the increase in demands for RMD. Moreover, the demand and export of RMD have also been reported to be linked to the fear of the Human Immunodeficiency Virus (HIV) (Barlow, 1999). Both rubber gloves and sheath contraceptives serve the purpose of infection control and protection. The prevalence of HIV/AIDS in the late 1980s had contributed to the rise in RMD demands, as descriptively reported by Barlow (1999), Ahituv et al. (1996), Ong (2001), Ong (2002), and Yip (2005).

The absolute number of people living with HIV in 2018 was around 37.9 million, which was high people compared to 9.1 million people in 1990, based on the data obtained from The Joint United Nations Programme on HIV/AIDS (UNAIDS). Instead of a onetime marginal use consideration, the usage of RMD as a proxy of awareness of prevention and infection control should be considered based on the absolute number of 
people living with HIV as the use of RMD is continuous and recurring. Any increase in the absolute number of people living with HIV is expected to increase the total demand for gloves and contraceptives.

United States (USA) is consistently Malaysia's largest export market for RMD. Fundamentally, the USA's anti-latex campaign was initiated when a citizen petition was submitted to the Food and Drugs Administration (FDA), USA, in early January 1998, asking for a ban of powdered latex gloves mainly due to protein allergy issue (Baker 2013). This marked critical point in the anti-latex campaign in the USA. As a response, cess on selected rubber products, which includes RMD, was introduced by the Malaysian government in 1999 with the initial short-term goal to neutralise the anti-latex campaigns in the 1990s in the United States (USA), besides the long-term goal to promote the export of rubber products though export promotion activities (EPAs). The export tax is imposed on the export of RMD under the Malaysian Rubber Board (Cess) Order 1999 and the Malaysian Rubber Board (Cess) Order 2009. The rate for cess was set at no more than $0.2 \%$ of the export earnings, and cess is used to fund the proposed (now already established) Malaysian Rubber Exports Promotion Council (MREPC) (Ghazali 1998a; Plan for Worldwide Office to Promote Malaysian Rubber Products 1998). The Government had earlier proposed a rate of $0.4 \%$ of the export earnings.

In Figure 1, the Balassa's Revealed Comparative Advantage (RCA) 5-year average shows that Malaysia's RMD export experienced the lowest RCA points between the years of 1994-1998 and 1999-2003. These periods (1994-1998 and 1999-2003) also coincide with the time of increasing pressures from the anti-latex campaigns. After the implementation of cess, RCA showed improvement in the periods of 2004-2008 and 2009-2013.

However, not all RMD exporters accept the implementation of cess positively. Malaysian rubber product manufacturers expressed fear that the cess structure that is too high for MREPC could affect the industry's growth (Ghazali 1998b). The Federation of Malaysian Manufacturers Malaysian Automotive Tyre Manufacturers Industry Group (FMM MATMIG),

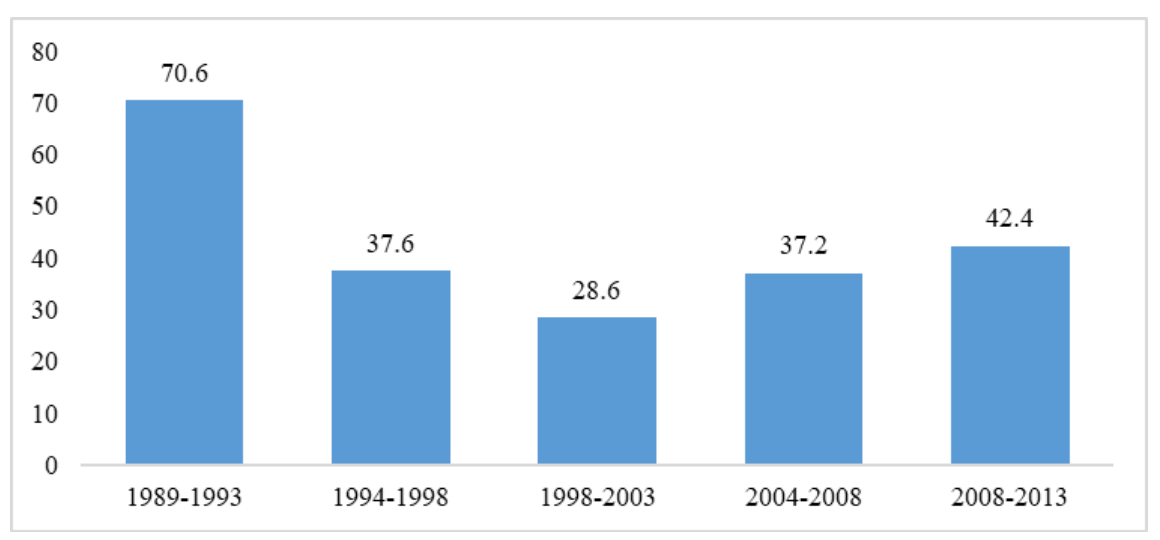

FIGURE 1: 5- year Balassa Revealed Comparative Advantage of Malaysia's RMD Export, 1989-2013 Source: Authors' calculation based on data from UN Comtrade and World Bank Development Indicators September 2017

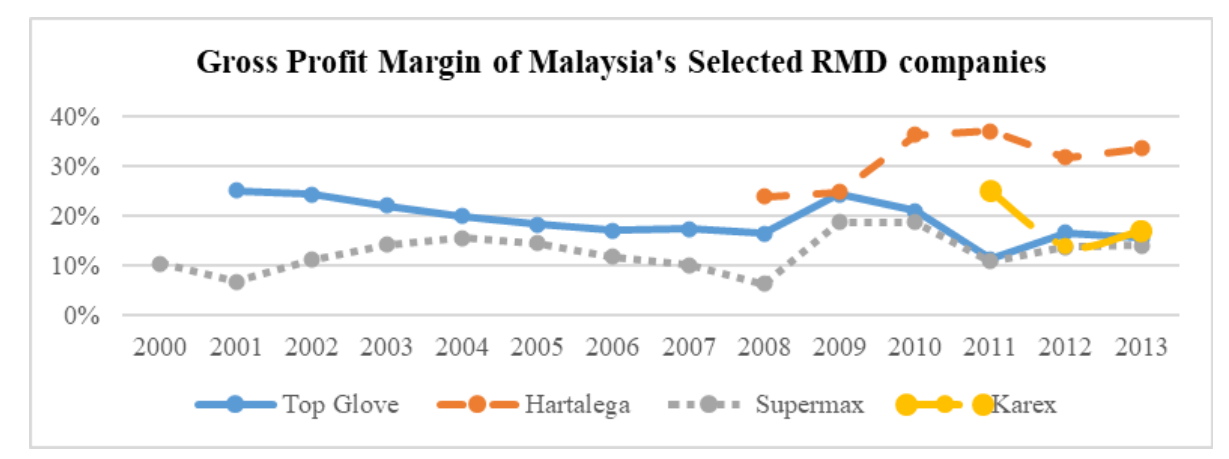

FIGURE 2: Gross profit margin (Gross profit/Net sales) of selected Malaysia's RMD companies Source: Annual Reports of Top Glove 2001-2013, Hartalega 2008-2013, Supermax 2000-2013, Karex's (2013)

Note: Top Glove was publicly listed in 2001, Hartalega was publicly listed in 2008, Supermax was publicly listed in 2000, Karex was listed in 2014 but provided public information on its revenue and profit from 2011 
and the Malaysian Rubber Product Manufacturers' Association (MRPMA) also repeatedly requested for a review of the cess imposition (Need for MREPC funding review 1999). Cess has been imposed on export revenue over the years despite the fluctuations of the profit margin in the RMD industry. Figure 2 shows the fluctuations in the profit margin of selected RMD companies in Malaysia. Despite the changes in the gross profit margin, some lower than $10 \%$ during certain years, the cess rate has remained unchanged.

Since cess on rubber products were imposed in 1999 , it is observed that there is no clear indication from the government about possible changes in policy. In 2005, the Plantation Industries and Commodities Ministry had stated the possibility of a review on grants (which refers to other bodies such as the Malaysian Rubber Board, not related to RMD) and cess in the rubber and rubber product industry (Ooi 2005). However, the same ministry opined later that the cess amount is small (Hamid \& Ismail 2016). It appears that the contention between the government and the industry members on the cess rate or even the presence of cess has been a long-standing issue even since before it was imposed until the present day. Although the latex protein allergy issue has affected the demand for Malaysian gloves, over the years, Malaysian manufacturers have produced more superior products to address the issue (Ong 2001). At the same time, Sundaram and Wee (2013) argued that different rates of export tax were applied on different commodities and products in Malaysia but no clear policy stance emerge from the different rates (applied).

MREPC $^{2}$ is the export promotion agency for Malaysian rubber products (MREPC, 2016) with functions similar to the export promotion agencies in other countries (Gil et al. 2008; Kang 2011) and Hayakawa et al. (2014). Lederman et al. (2010) noted that export promotion agencies assist potential export companies to explore their markets and provide these companies with an understanding of products demanded in the global market. MREPC's survey in 2006 also showed that small and medium rubber product companies (SMEs) faced difficulties to find and identify potential buyers in foreign markets and adversity to obtain the information about the overseas markets (Ong 2014). As such, MREPC's role as an export promotion agency is beneficial, particularly to these SMEs.

Based on past literature, EPA included a wide array of activities but are commonly categorised into (1) establishment of overseas office, (2) official visits by state delegation, and (3) participation in trade and business activities overseas organised by trade promotion bodies. MREPC had set up its overseas office in the USA in 2001, office in the United Kingdom (UK) in 2010, and another office in China in 2011. Other than being in-charge-of EPAs, MREPC also plays vital role as an agency of the Ministry of Plantation Industries and Commodities (MPIC). Based on reports of overseas missions by MREPC, MREPC also supports other Malaysian commodities promotions such as Palm Oil Trade Fair and Seminar (POTS) in India 2014 (MREPC 2014), POTS China 2016 (MREPC 2016), POTS Myanmar 2013 (MREPC 2013).

There is an increasing need to study the economic effects of cess because Malaysian rubber product firms have repeatedly requested for the reduction or complete abolishment of the cess on rubber products through associations such as the FMM MATMIG, MRPMA and Malaysian Rubber Glove Manufacturers' Association (MARGMA). Notwithstanding these calls, the government appears to maintain the status quo on cess. However, there has been no comprehensive study on whether cess is a significant determinant that affects the export of rubber products from Malaysia, and the assessment of major EPAs on RMD export. Moreover, previous studies usually focus on tariffs, quotas, and other non-tariff measures, but the study on export taxes is still relatively scarce. Solleder (2013) claimed that a total of 81 products and 75 products from Malaysia at HS-6 digits level were subjected to export tax in 2007 and 2011, respectively. However, the study by Solleder (2013) did not cover cessable RMD exported from Malaysia.

Hence, this study will assess the effect of export tax (cess), along with the effect of direct EPAs on RMD export. Very few studies had focused on the effect of export taxes on rubber products with particular attention to rubber gloves and sheath contraceptives, given the importance of rubber products and RMD as one of the top ten exports of Malaysia. The findings of this paper are relevant to the policy debate among the various stakeholders on the cess imposition on RMD, and subsequently, the EPAs funded by cess to strengthen the RMD export. As this study gives specific focus on Malaysia's RMD export, this study is able to contribute to the analysis of the main EPAs of the overseas office, trade mission, and trade fairs participation in a single study. Past literature usually focused on one of the three EPAs only due to the broad scope of the export/trade products.

The remainder of the paper is organised as follows: Next, the literature review is provided in Section 2. This is followed by the data and methods section. Section 4 presents the results and discussion and the Conclusion in the final section ends this paper.

\section{LITERATURE REVIEW}

\section{EFFECT OF EXPORT TAX}

Most export tax studies are prepared by international organisations due to the difficulty and complexity required in collecting the relevant data (Solleder 2013). This also explains the lack of economic literature on 
the effects of export tax, as it is challenging to gather a comprehensive cross-country comparison dataset on export tax for economic analysis. Past literature showed that the decrease in exports is due to the increase in cost with the imposition of export tax. Bouët and Laborde (2010) found that in the case of a small country applying export tax, there is a motivation for domestic producers to supply to the local market rather than the world market as they are not taxed when selling domestically. This situation increases supply and hence reduces the domestic price. As the domestic price reaches the level of the world price net of tax, the producers are indifferent between exporting and serving the domestic market. Next, Bouët and Laborde (2010) further extend their analysis to a large country. When a large country applies an export tax, it can influence the world price of the taxed goods. A large country, by definition, is assumed to have a significant share of the world exports. The government revenues are augmented by the rise of the world price (of the taxed good).

Next, Repetto (1972) highlighted the evidence that export taxes reduce export. It was found that more than a third of the export proceeds of jute in Pakistan during 1967-1969 were taxed. Furthermore, Golub and Finger (1979) estimated that local companies' export revenue of primary commodities' processing would increase by $9 \%$ in the developing countries and decline by less than $1 \%$ in the developed countries with the imposition of export tax. Bouët et al. (2014) found that both consumers and producers throughout the world benefit from the removal of the differential export taxes (DET) in the oilseeds value chains. This leads to a significant expansion of the world production of all activities along the value chain.

Meanwhile, Solleder (2013) empirically estimated the trade effects of export taxes in a multi-country and multi-product setting using the gravity model. It was highlighted as the first study to evaluate trade effects of export taxes empirically. Solleder (2013) explained that the study covered more that $90 \%$ of the world's export tax based on pooled data in 2007 and 2010 for 20 exporting countries and 169 importing partner countries. The results indicated that the elasticity of trade quantities to tax is -1.8 on average, which means that the burden of export taxes is shared by exporters and importers and that export taxes play a role in the rise of world prices. Hence, it is shown that the imposed export tax was due to various reasons ${ }^{3}$, and mostly it has a significantly negative effect or no significant effect on export or trade.

\section{EFFECT OF EXPORT PROMOTION ACTIVITIES}

As for EPAs, many of the empirical literature did not provide evidence of the positive impact of the EPAs on exports in the past 10 years until 2001 (Gençtürk \& Kotabe 2001). However, recent studies have provided more evidence about the positive effects of export promotion agencies and their activities (Hayakawa 2014). Nonetheless, there is a lack of data to support this evidence further, as raised by Nothdurft (1992). Furthermore, according to Onunkwo and Epperson (2000), by using a single-equation framework, the US export promotion activities for pecans had a positive effect on exports, with higher return returns per dollar of promotion spending for the European Union (EU) (USD6.75) than for Asia (USD6.45). The export promotion for almonds in Asia and the walnut promotion in the EU was also found to provide spill-over benefits for pecan exports. Export promotion activities based on market segmentation was also recommended to maximise the impact of such activities.

Against the backdrop of globalisation and the cost of maintaining foreign missions, Rose (2007) examined if foreign missions have a systematic link to exports. Rose (2007) used the gravity model framework and found that each foreign mission (embassy or consulate) was linked to higher exports, which were estimated at $6-10 \%$. The first foreign mission has a more massive effect on higher exports compared to subsequent missions, and the creation of an embassy has a larger effect than a consulate. Gil et al. (2008) findings showed that regional export promotion agencies (of 17 states in Spain) increased their trade, and their impact was larger than the impact of Spanish embassies and consulates (which are more focused on bilateral affairs). The trade promotion agencies can focus exclusively on increasing trade and investments. Meanwhile, Kaiser et al. (2003) found that the EPAs had increased the export of Californian raisins to Japan and the UK. Using a single equation import demand model for raisins, the benefit outstripped the cost by a ratio of 15:1 (UK) and 15:1 (Japan). The use of optimality analysis also showed that more could be tapped from export promotion in the UK, although the benefit in Japan is already optimal.

Based on the studies without a detailed budget of the EPA, limited studies had expanded to those with the EPA's budget details. Kang (2011) extended the findings of the positive effects of export promotions using the budget for activities by the overseas office of Korean Trade and Investment Promotion Agency (KOTRA) as a dependent variable of interest compared to the number of overseas offices used in Rose (2007) and Gil et al. (2008). Using the gravity model as well, Kang (2011) found that KOTRA is significant in increasing the exports, where a $10 \%$ increase in the EPA budget had increased the exports by $2.45 \%-6.34 \%$. Furthermore, Hayakawa's (2014) results further shows that Japan External Trade Organization (JETRO) and KOTRA export promotion activities overseas had increased Japan's and Korea's exports, respectively, and the effect of setting up of an overseas office was not less than half of the signing of an FTA. 
The second form of EPA is the state visits or trade missions. Cassey (2007) provided evidence that there is a positive relationship between trade missions of US governors and exports. This was viewed using the fixedeffect model, where countries that have massive imports from the US were selected. In a more political economy approach, Fuchs and Klann (2011) empirically examined whether countries that received the Dalai Lama despite China's opposition showed a significant fall in their exports to China. Their findings showed that countries that officially received the Dalai Lama at the highest political level showed a reduction in their exports to China, but this was largely driven by decreased exports of machinery and transport equipment. The effect disappeared two years after a meeting took place.

However, not all studies on trade missions showed a positive relationship between trade missions and exports. In the case of Canada from 1992-2003, Head and Ries (2010) found that Canadian trade to be higher prior to the missions. Hence, the study showed that the evidence did not support employing trade missions as an effective tool to increase bilateral trade. The econometric impact is that while Canadian trade, subsequent to a mission, was higher with mission-targeted countries, it was also already higher prior to the missions. The Canadian trade missions are largely divided into two categories of Team Canada missions (TCs) headed by the Prime Minister. At the same time, the Canada Trade Missions (CTMs) are led by the Minister of International Trade.

\section{DATA AND METHODS}

This section explains the gravity model used to examine the effects of cess and EPAs, respectively, on Malaysia's RMD export. The estimation techniques of panel estimation of fixed effect (FE) and random effect (RE) are also explained. It is then followed by data descriptions and the source of data.

\section{EFFECT OF CESS ON RMD EXPORT}

The gravity model of trade is one of the most frequently applied models in the study of international trade since the model was first applied in a seminal work by Tinbergen (1962). Tinbergen (1962) highlighted that the Gross National Product of exporting and importing countries and the distance between the countries as the main explanatory variables of the gravity model.

According to Akhvlediani and Sledziewska (2017), the specification of the gravity model for estimation purposes varies according to the approaches of different authors even though the gravity model is already commonly accepted as a standard tool to analyse trade flows. The standard gravity model of trade includes economic size and geographical distance (representing the cost of transportation) variables. The model, in its simplest form, which is in log-linearised form, is as follows:

$$
\ln X_{i j}=\beta_{0 i}+\beta_{1} \ln Y_{i t}+\beta_{2} \ln Y_{j t}+\beta_{3} \ln D_{i j}+\mu_{i j}
$$

where

is the RMD exported by country $i$ to country $j$;

$Y_{i}$ is the GDP of country $i$,

$Y_{j}$ is the GDP of country $j$,

$D_{i j}^{j}$ is the distance separating the countries,

is a log-normally distributed error term.

$i$ is the exporting country (reporter $i$ : Malaysia),

$j$ is the importing country (partner $j$ : importing countries).

Although the coefficient of distance on trade is generally found to increase rather than decrease through time, distance is still a relevant key variable of study in international trade despite the growing globalisation. The issue of 'death of distance' is widely confined to bilateral trade between rich countries, and not for poor countries (Brun et al., 2005). The role of distance is important as it is a proxy of transportation cost, and the gravity model continues to remain relevant, especially in studying trade flows of poor countries.

Some gravity model studies, however, found that distance may not always be a significant variable. Turkey's trade of vegetables and fruits is not significantly affected by distance transportation costs (Atici \& Bulent Guloglu 2006). The study highlighted the reasons for (1) Turkey has close political and economic relationships with the EU when compared with its neighbouring countries, and (2) most of the fruit exports consist of nuts that have a long shelf life. Meanwhile, Barnes and Bosworth (2015) discussed that there is no statistically significant relationship in the gravity model between distance and the trade of LNG.

In the case of Malaysia's trade with the Gulf Cooperation Council (GCC) countries, Devadason et al. (2014) found that the distance variable is not significant because for the type of goods traded which Malaysia's manufactured goods (HS25-57) exported to the GCC are not produced by regional or neighbouring countries of Malaysia. There are also cases where distance turns out to have a positive coefficient. Dreyer (2014) argued that the distance variable shows a positive effect on agricultural trade because distance not only represent transportation cost but also the differences onin climate, land and agriculture products among partner countries. Akhmadi (2017) also argued that a large number of partners in the study (Indonesia's agriculture commodity, 2000-2014) were not neighbouring countries, hence showed that the positive coefficient of distance also depends on the trade partners of the products, and not merely transportation cost factor.

The following gravity model, adapted from Solleder (2013), is used to examine the effect of cess on the export of RMD: 


$$
\begin{aligned}
\ln X_{i j}= & \beta_{0 i}+\beta_{1} \ln Y_{i t}+\beta_{2} \ln Y_{j t}+\beta_{3} \ln D_{i j}+\beta_{4} \ln H I V_{t}+ \\
& +\beta_{5} \ln T_{i j t}+\mu_{i j}
\end{aligned}
$$

where

$T$ is the cess on RMD from country $i$ to country $j$, $H I V$ is the number of people living with HIV globally.

The independent variables are expressed in natural logarithms $(l n)$ except for dummy variables. The size of the importing economy determines import demand while the size of the exporting economy represents a group of factors determining export supply.

Cess used in this study is in the form of a dummy variable where the period prior to implementation (before 1999) is 0 , and after implementation is 1 . As observed in Solleder (2013), cess is treated as a dummy variable, and it is expected that cess has a negative effect on the export of RMD, and Malaysia will export less of RMD during the effective period of cess imposition. Based on earlier studies (Barlow 1999; Ong 2001; 2002; Yip 2004), the number of people living with Human Immunodeficiency Virus (HIV) is also included as explanatory variables in which the discovery and development of HIV have contributed to the growth of rubber gloves and sheath contraceptives as the awareness of prevention and infection control increased.

\section{EFFECT OF EXPORT PROMOTION ACTIVITIES ON RMD EXPORT}

The second part of this study focused on the impact of EPAs (funded by cess) on the RMD export. The subsample of the data from the period of 2004-2013 was used in this section as EPAs recorded by MREPC was only available for the year 2004 onwards. The effect of the presence of overseas offices of MREPC, participation in trade fairs, and trade missions, were based on the earliest model by Rose (2007), and they were examined in the gravity model equation provided below:

$$
\begin{aligned}
\ln X_{i j}= & \beta_{0 i}+\beta_{1} \ln Y_{i t}+\beta_{2} \ln Y_{j t}+\beta_{3} \ln D_{i j}+\beta_{4} \ln H I V_{t}+ \\
& \beta_{5} \ln \operatorname{FFFICE}_{i j t}+\beta_{6} \text { TFdummy }_{i j t}+ \\
& \beta_{7} \operatorname{lnMISSION} \operatorname{Nijt}_{i j}+\mu_{i j}
\end{aligned}
$$

where

OFFICE is the overseas office of MREPC

MISSION is a trade mission attended by MREPC, either organised by MREPC or co-organised with other organisations

$T F_{\text {dummy }}$ is the trade fairs attended as listed by MREPC

For the overseas offices, this study adapted Rose's (2007) approach, as it is challenging to identify the importance of each office although they are headed by different levels of seniority, namely, a Director for the USA and UK office, respectively, and a Representative for the China office. As such, all overseas offices are treated equally based on Rose (2007). The mission attended by MREPC is similar to the CTMs, noted in Head and Ries (2010), where the missions are usually headed by the Minister of Plantation Industries and Commodities. Participations in trade fairs are recorded as dummy variables each year per country, as it is difficult to ascertain the importance of each trade fair attended.

\section{EMPIRICAL TECHNIQUE}

The choice of method (to estimate the gravity model) should be based on both economic and econometric considerations (Linders \& De Groot 2006). Panel data using FE estimation usually involves the absence of uncontrolled heterogeneity. The FE estimation method assesses the impacts of independent variables on dependent variables, but FE cannot estimate the coefficients for variables with a fixed value over time, such as distances between the countries. Meanwhile, RE can estimate the coefficients of the variables which have a fixed value over time but cannot give good results if the samples selected in the model are heterogeneous (Bui \& Chen 2015). Hujala et al. (2009) noted that unlike the FE estimator, the RE estimator does not automatically drop the time-invariant regressors. The FE estimation will not show the coefficients of distance and other dummy variables. To determine whether RE is appropriate, the Breusch-Pagan (1980) and Lagrange Multiplier (LM) tests were being employed.

As applied in Bui and Chen (2015), the Hausman test is conducted to check on the most suitable estimation method for the model in this study. To conduct the Hausman test, the model must first be estimated with a RE specification. The null hypothesis of the Hausman test is that there is no correlation between the individual effects and the regressors. If the null hypothesis is rejected, the alternative hypothesis is accepted, whereby there is a correlation between the individual effects and the regressors. Acceptance of the alternative hypothesis indicates that the FE specification is better compared to the RE panel estimation.

Past studies usually highlight the multicollinearity issue in the gravity model's estimations. Some commonly used augmented variables in the gravity model studies have a strong significance. Still, at the same time, they may pose high multicollinearity problems, which could lead to inaccurate estimation of parameters (Narayan \& Nguyen 2016). The correlation matrix for the independent variables shows the degree of correlation between the variables. 


\section{SOURCE OF DATA}

The dataset is a balanced panel dataset with 725 observations for the dependent variable for the selected 29 countries (refer to Appendix A) in a period of 25 years from 1989-20134. This dependent variable in this study is the export of rubber gloves and sheath contraceptives from Malaysia to selected trading partners. The export data of rubber gloves and sheath contraceptives are obtained from UN Comtrade under the HS 6-digit of 401511, 401519, and 401410. The importing countries in this study involve the top 20 importers of rubber gloves and sheath contraceptives or trading partners which have free trade agreements, which had already taken effect with Malaysia. These countries represented about $85 \%$ of the imports of RMD from Malaysia in 2013. For EPAs effect estimation, the sub-sample of the data used is from 2004-2013 because the EPAs data recorded by MREPC is only available from 2004 onwards.

The Gross Domestic Product (GDP), the data is sourced from the World Bank. The distance data (D) that was used for measuring the distance between the exporting country and the importing country is obtained from the Centre d'Etudes Prospectives et d'Informations Internationales (CEPII) dataset, while the cess data $(T)$ is obtained from the Malaysian Rubber Board. This source is different from Solleder (2013), which captured the export tax data of Malaysian products at HS-6 digits level from the Ministry of International Trade and Industry (MITI) that were subjected to export tax in 2007 and 2011.

The data on EPAs for RMDis based on the EPAs listed on MREPC Event listing which is then tabulated by the authors. The number of people living with HIV/ AIDS is obtained from UNAIDS and World Health Organisation (WHO) as a proxy of increased healthcare awareness and education about the prevention of diseases.

\section{EMPIRICAL RESULTS AND DISCUSSION}

Table 1 shows the descriptive statistics of the balanced panel dataset with 725 observations for each variable. Table 2 and Table 3 show the results of FE and RE for Equation (2) and (3), respectively. Appendix B shows the correlation matrix for the full sample used in Equation 2, while Appendix C shows the correlation matrix for the sub-sample in Equation 3, respectively. Given the high correlation between the importers' $G D P$ and $H I V$ in the sub-sample data, the HIV variable is not entered into the estimation as the problem of multicollinearity may lead to misleading empirical results.

\section{EFFECT OF CESS ON RMD EXPORT}

The Hausman test results shown in Table 2 show that the null hypothesis is linked to RE that is consistent and efficient is rejected. Therefore, the FE is the preferred model. Malaysia's exporter's and importers' GDP $\left(Y_{i t}\right.$ and $\left.Y_{j t}\right)$ have a significant positive relationship with Malaysia's RMD export, which shows that the economic size of Malaysia and the economic growth of the importing countries are important to sustain and increase the demands of RMD export from Malaysia. In this study, it is shown that distance is insignificant, which is less common for gravity model studies. Similar results had previously been observed in Atici and Bulent Guloglu (2006), Barnes and Bosworth (2015), and Devadason et al. (2014).

On the other hand, cess $\left(T_{i t}\right)$ has a significant negative relationship with Malaysia's RMD export. This result implies that there is a potential opportunity cost in the imposition of cess on RMD export. The opportunity cost of implementing cess on RMD is the potential loss of a higher RMD export, ceteris paribus. However, it is also important to note that cess was first implemented to lobby against anti-latex campaigns in 1998, and the proceeds have been used over the years for export promotion activities (see further discussion on EPA results in Table 4).

Meanwhile, although the increased education on the prevention control and early fear of HIV has been highlighted by several studies to boost RMD export in the late 1980s; it is observed that the variable $H I V_{t}$. which indicates the increase in the number of people living with HIV, is not a significant variable affecting the RMD export.

\section{EFFECT OF EXPORT PROMOTION ACTIVITIES ON RMD EXPORT}

In Table 3, the Hausman test that the null hypothesis indicates that the $\mathrm{RE}$ is consistent and efficient. Therefore, it is not rejected. Therefore, the RE is the preferred model. Malaysia's and the importers' GDP have a significant positive relationship, which was also shown in Table 2. However, in this sub-sample, the result of distance is a significant positive, which is unusual in gravity model estimations. This is similar to Dreyer (2014) and Akhmadi (2017), where a specific product, in a smaller time period is investigated, and a large number of sample countries are not neighbouring countries. Meanwhile, out of the three separate categories of EPAs comprising participation in foreign trade fairs, trade missions by Malaysian delegations to target destinations, and the presence of MREPC overseas offices, only the presence of MREPC overseas 
office $\left(O F F I C E_{i j t}\right)$ has shown significance. However, the trade missions $\left(M_{S S S I O N}\right.$ ) has also shown positive coefficients in the estimation. MREPC's presence in the USA, UK, and China has proven to be important and reflects on the importance of these countries to Malaysia's RMD export.

Given that the USA is Malaysia's largest RMD importer, the presence of the MREPC office in the USA shows the continuous effort to address the issue of latex allergy. The strong presence such as MREPC's frequent addresses to the Joint Committee of Public Health of various states in the USA (Yip, 2017; 2015) shows that among the EPAs by USA office includes a consistent handling of the prime initial objective of tackling the anti-latex campaigns. This can be linked to Hayakawa (2014) argument that the effect of setting up of an overseas office is at least more than half of the signing of an FTA.

The initial expectation for the trade mission is that this variable is significant, based on a review of past literature. The results of this study show that the trade mission shows a positive sign, but it is not significant.
The EPAs of trade missions may not have shown a direct impact as MREPC, as an agency of MPIC that also participates in the missions such as POTS, organised by the Ministry. It may be more effective for the ministry and the related agencies as a whole but such is not the case when the RMD export is examined separately. Meanwhile, for trade fairs $\left(T F_{i j t}\right)$ (negative coefficient, not significant), the countries for trade fairs are quite diversified, based on the data compiled from MREPC, and some are new target export countries which may not immediately show a direct effect in terms of an export increase.

Given the mutual importance of Malaysia's and importers' GDP, companies with limited resources, especially small and medium companies, can choose to participate in MREPC-subsidised international trade fairs based on consideration of the higher-income of importers as a priority even though these countries maybe farther. Some trade missions or trade fairs may be organised at the same time period, and the results of the economic size of importing countries provide clearer information to make more well-informed decision.

TABLE 1. Descriptive Statistics

\begin{tabular}{lccccc}
\hline & Export & Importers' GDP & Exporter's GDP & Distance & No. of people living with HIV \\
\hline Mean & $41,700,143$ & $1,199,432,613,523$ & $141,805,160,000$ & 7,732 & $25,368,000$ \\
Std. Dev. & $116,073,481$ & $2,266,410,039,765$ & $84,189,904,996$ & 4,949 & $9,313,830$ \\
Minimum & 0 & $346,000,000$ & $41,095,000,000$ & 316 & 400,000 \\
Maximum & $1,189,498,939$ & $16,663,150,000,000$ & $323,342,000,000$ & 16,562 & $35,200,000$ \\
\hline
\end{tabular}

Note: Std. Dev. refers to Standard Deviation

TABLE 2. Estimation Results of OLS, FE, RE for the impact of cess

\begin{tabular}{lcc}
\hline Variables & FE & RE \\
\hline $\ln Y_{i t}$ & $0.481352^{* * *}$ & $0.867878^{* * *}$ \\
& $(0.0000)$ & $(0.0025)$ \\
$\ln Y_{j t}$ & $1.647961^{* * *}$ & $1.215117^{* * *}$ \\
& $(0.0000)$ & $(0.0000)$ \\
$\ln D_{i j}$ & - & -0.124882 \\
$T_{i t}$ & & $(0.6838)$ \\
$\ln H I V_{t}$ & $-0.250336^{* *}$ & $-0.248121^{* *}$ \\
& $(0.0337)$ & $(0.0341)$ \\
$\mathrm{C}$ & $0.890508^{* * *}$ & $0.878052^{* * *}$ \\
$\mathrm{R}^{2}$ & $(0.0000)$ & $(0.0000)$ \\
Adj R & -56.03020 & -53.09451 \\
Hausman test & 0.652827 & 0.438951 \\
Hausman test Chi-sq & 0.636773 & 0.435049 \\
$\mathrm{~N}$ & - & $0.08^{*}$ \\
\hline
\end{tabular}

Notes: Values in parentheses are p-values. $* * *$ significant at $1 \%, * *$ significant at $5 \%$ and $*$ significant at $10 \%$ 
TABLE 3. Estimation Results of OLS, FE, RE for the impact of EPAs

\begin{tabular}{|c|c|c|}
\hline Variables & $\mathrm{FE}$ & $\mathrm{RE}$ \\
\hline $\ln Y_{i t}$ & $\begin{array}{c}1.163536^{* * * *} \\
(0.0000)\end{array}$ & $\begin{array}{c}1.015924 * * * \\
(0.0000)\end{array}$ \\
\hline $\ln Y_{j t}$ & $\begin{array}{c}0.635953 * * * \\
(0.0000)\end{array}$ & $\begin{array}{c}0.824579 * * * \\
(0.0000)\end{array}$ \\
\hline $\ln D_{i j}$ & - & $\begin{array}{l}0.259324 * * * \\
\quad(0.0000)\end{array}$ \\
\hline $\operatorname{lnOFFICE_{ijt}}$ & $\begin{array}{c}-0.072130 \\
(0.2204)\end{array}$ & $\begin{array}{c}0.155033^{*} \\
(0.0883)\end{array}$ \\
\hline $\operatorname{lnMISSION}_{i j t}$ & $\begin{array}{c}0.010305 \\
(0.8031)\end{array}$ & $\begin{array}{c}0.052843 \\
(0.5691)\end{array}$ \\
\hline$T F_{i j t}$ & $\begin{array}{c}0.063346^{* * * *} \\
(0.2059)\end{array}$ & $\begin{array}{c}-0.194148 \\
(0.1156)\end{array}$ \\
\hline $\mathrm{C}$ & -31.02429 & -33.78316 \\
\hline $\mathrm{R}^{2}$ & 0.981608 & 0.818899 \\
\hline Adj $R^{2}$ & 0.979237 & 0.815060 \\
\hline Hausman test & - & 0.99 \\
\hline Hausman test Chi-sq & - & 5 \\
\hline $\mathrm{N}$ & 725 & 725 \\
\hline
\end{tabular}

Notes: Values in parentheses are p-values. $* * *$ significant at $1 \%, * *$ significant at $5 \%$ and $*$ significant at $10 \%$

\section{CONCLUSION}

This study provides evidence that cess negatively affects the export of RMD, which has been a cause of concern among RMD exporters and trade associations. Balancing the view on cess which is also used for export promotion efforts, however, it is also observed that export promotion activities (EPAs) for RMD have contributed positively to Malaysia's RMD export growth.

While cess shows a negative significant relationship with the export of RMD, the current rate is already considerably low (compared against products such as processed rubber, sawn logs, rubber apparel, oils and fats, crude palm oil with the effective export duty ranging between $0.25 \%-7.61 \%$ as listed by Broadway et al. (1995)). Furthermore, the tax rate that is based on weight (such as those imposed on natural rubber) may not be practical. When exporters are faced with high production costs and low profit (see earlier Figure 2), which may dampen Malaysia's RMD export, the government may consider flexibility during a certain period of time. Moreover, the importing country's GDP shows that the economic size of major trading partners is vital to support the import of RMD from Malaysia. Hence, EPAs should be focused on trading partners which have large and sustainable GDP. As such, market promotion incentives may be formulated for higher allocation for export promotion in countries with higher income and large country, while still maintaining a reasonable allocation for EPAs for smaller or, middle and low-income countries. In addition, cess is used to fund export promotion activities and benefits exporters, especially small companies that may not have much support for export promotion activities themselves. As MREPC provides similar EPA benefits to be tapped by rubber product companies, small and medium RMD companies may tap on the EPAs benefits to get connected with potential customers in foreign markets (a challenge identified in MREPC's 2006 survey).

Furthermore, market promotion activities can also be expanded to cover a wider scope of activities, such as automation subsidies and brand name purchases, ${ }^{5}$ to ensure that the cess is used in a beneficial way for the industry members. The limited information on the details of cess and EPAs (as noted in Solleder (2013) for cess, and Nothdurft (1992) for EPAs) of Malaysia's RMD export provides motivation for future studies to explore on the details of the collection of cess and expenditure for EPAs when such details are released. Which this will provide better insights to assist in the policy-making efforts for Malaysia's RMD and rubber products export.

\section{NOTES}

1. Rubber catheters are not included in this study due to the lack of data on the exports of solely rubber catheters. The currently available Harmonised System (HS) codes on catheters include other types of catheters, including those made from plastic.

2. While MREPC is tasked to run market promotion activities for export of rubber products, there is no public information on the total expenditure for such activities. Nevertheless, MREPC does list 
the type of incentive for rubber product exporters. The incentives vary and are relatively broad in nature which includes incentive for marketing and promotion activities, certifications and registration, testing, and subsidies for website development.

3. Reubens (1956) explained that export tax is imposed mainly (1) in entrepôt where import taxes were considered disadvantageous to trade in general as well as to the home-country's exports; (2) in monopolistic positions (example of Ceylon's command over cinnamon and quinine); and (3) in regions where no more than a modest and easily collected revenue from relatively light taxes was favourable.

4. The initial list contains 31 countries. However, Laos and Myanmar were dropped from the dataset as there are insufficient and inconsistent trade data records from these countries.

5. One such example is Karex's asset purchase of TheyFit's right, title and interest to assets. which owns the patents, trade names and trademarks for contraceptives manufactured, marketed and sold under the TheyFit brand in the U.K and Europe. (Unit signs pact to buy US condom maker for $\$ 1.3 \mathrm{~m}, 2016$ )

\section{REFERENCES}

Ahituv, A., Hotz, V. J., \& Philipson, T. 1996. The responsiveness of the demand for condoms to the local prevalence of AIDS. Journal of Human Resources: 869-897.

Akhmadi, H. 2017. Assessment the Impact of Asean Free Trade Area (AFTA) on Exports of Indonesian Agricultural Commodity. AGRARIS: Journal of Agribusiness and Rural Development Research 3(1): 9-14.

Akhvlediani, T., \& Śledziewska, K. 2017. Implications of the European integration: revisiting the hypothesis of 'huband-spokes' model. Baltic Journal of Economics 17(1): 45-56.

Atici, C., \& Guloglu, B. 2006. Gravity model of Turkey's fresh and processed fruit and vegetable export to the EU: A panel data analysis. Journal of International Food and Agribusiness Marketing 18(3-4): 7-21.

Balassa, B. 1965. Trade Liberalization and Revealed Comparative Advantage. The Manchester School of Economic and Social Studies 119: 93-123.

Barlow, C. (Ed.). 1999. Institutions and economic change in Southeast Asia: The context of development from the 1960 s to the 1990s. Edward Elgar Publishing.

Barnes, R., \& Bosworth, R. 2015. LNG is linking regional natural gas markets: Evidence from the gravity model. Energy Economics 47: 11-17.

Baker, C. 2013. A System In Need of Repair-Medical Device Regulation: The Example of Latex Medical Gloves. Synthesis: A Journal of Science, Technology, Ethics, and Policy 4(1): G32-G39.

Barlow, C., (ed.), 1999. Institutions and Economic Change in Southeast Asia, Cheltenham, UK: Edward Elgar.

Bouët, A., Laborde-Debucquet, D., Dienesch, E. \&0 Elliott, K. (2010). The costs and benefits of duty-free, quota-free market access for poor countries: Who and what matters. Journal of Globalization and Development 3(1).

Bouët, A., \& Laborde, D. 2010. Economics of Export Taxation in a Context of Food Crisis. IFPRI Discussion Paper 994 and "The Economics of Export Taxes in the Context of Food Security in OECD, The Economic Impact of Export Restrictions on Raw Materials, OECD Publishing. 50.

Bouët, A., Estrades, C., \& Laborde, D. 2014. Differential export taxes along the oilseeds value chain: a partial equilibrium analysis. American Journal of Agricultural Economics, 96(3), 924-938.

Boadway, R., Chua, D., \& Flatters, F. 1995. Indirect Taxes and Investment Incentives in Malaysia In Shah, A., (ed.). Fiscal Incentives for Investment and Innovation. Washington DC: The World Bank and Oxford University Press

Bui, T. H. H., \& Chen, Q. 2015. An Analysis of Factors Influencing Rice Export in Vietnam Based on Gravity Model. Journal of the Knowledge Economy 1-15.

Cassey, A. J. 2007. State trade missions. In Paper Seminar, School of Economic Sciences, Washington State University, Spring (Vol. 2008, pp. 1-29).

Careplus Group Berhad. 2017. Careplus Group Berhad Annual Report 2017. Retrieved from http://disclosure.bursamalaysia.com/FileAccess/ apbursaweb/download?id=180231 andname=EA_DS ATTACHMENTS

Comfort Rubber Gloves Berhad. 2016. Comfort Rubber Gloves Berhad Annual Report 2016. Retrieved from http://disclosure.bursamalaysia.com/FileAccess/ apbursaweb/ download?id=1 7568 6andname=EA_DS ATTACHMENTS

Department of Statistics, Malaysia .2015. Malaysia External Trade Statistics Online (METS Online). Retrieved from http://www.statistics.gov.my/ portal/index.php?option $=$ com_contentandview $=$ articleandid $=2470$ andItemid $=111$ andlang $=\mathrm{en}$

Devadason, E. S., Baharumshah, A. Z., \& Subramaniam, T. 2014. Leveraging trade opportunities with non-traditional partners: the Malaysia-GCC perspective. The Pacific Review 27(1): 97-122.

Dreyer, H. 2014. Misaligned distance: Why distance can have a positive effect on trade in agricultural (No. 329-201612981, pp. 1-18).

Food and Agriculture Organisation. Retrieved from http:// www.fao.org/statistics/en/

Fuchs, A., \& Klann, N. H. 2013. Paying a visit: The Dalai Lama effect on international trade. Journal of International Economics 91(1): 164-177.

Gençtürk, E. F., \& Kotabe, M. 2001. The effect of export assistance program usage on export performance: a contingency explanation. Journal of International Marketing 9(2): 51-72.

Ghazali, F. 1998a. Move to sort out NR council funding. Business Times Retrieved from https://searc h.proquest. com

Ghazali, F. 1998b. High levy may stifle latex industry growth. Business Times Retrieved from https:/ /search.proquest. com

Gil, S., Llorca, R., \& Serrano, J. A. M. 2008. Measuring the impact of regional export promotion: The Spanish case. Papers in Regional Science 87(1): 139-146. 
Golub, S. S., \& Finger, J. M. 1979. The processing of primary commodities: Effects of developed-country tariff escalation and developing-country export taxes. The Journal of Political Economy: 559-577.

Hamid, A. J. \& Ismail, Z. I. 2016. Downstream focus to lift commodity exports. New Straits Times Retrieved from https://www.nst.com.my/news/2016/07/159496/ downstream-focus-lift-commodity-exports-video

Hayakawa, K., Lee, H. H., \& Park, D. 2014. Do export promotion agencies increase exports?. The Developing Economies 52(3): 241-261.

Hayakawa, K., \& Kimura, F. 2014. How do free trade agreements reduce tariff rates and non-tariff barriers (No. 446). Institute of Developing Economies, Japan External Trade Organization (JETRO).

Head, K., \& Ries, J. 2010. Do trade missions increase trade? Canadian Journal of Economics/ Revue canadienne d'économique 43(3): 754-775.

Hujala, M., Arminen, H., Hill, R. C., \& Puumalainen, K. 2013. Explaining the shifts of international trade in pulp and paper industry. Forest Science 59(2): 211-222.

Kaiser, H. M., Liu, D. J., \& Consignado, T. 2003. An economic analysis of California raisin export promotion. Agribusiness 19(2): 189-201.

Kang, K. 2011. Overseas network of export promotion agency and export performance: the Korean case. Contemporary Economic Policy 29(2): 274-283.

Karex Berhad. 2014. Financial Info. Retrieved from http:// www.karex.com.my/financial-info/

Karex Berhad. 2017. Karex Berhad Annual Report 2017. Retrieved from http://disclosure.bursamalaysia. com/File Access / a pbursaweb/download? $\mathrm{id}=177409$ andname $=$ EADSATTACHMENTS

Kossan Rubber Berhad. 2017. Kossan Rubber Berhad Annual Report. Retrieved from http://disclosure. bursamalaysia.com/FileAccess/apbursaweb/ download? id=179718 andname=EA_DS ATTACHMENTS

Laborde, D., Estrades, C., \& Bouët, A. 2013. A global assessment of the economic effects of export taxes. The World Economy 36(10): 1333-1354.

Lederman, D., Olarreaga, M., \& Payton, L. 2010. Export promotion agencies: Do they work?. Journal of Development Economics 91(2): 257-265.

Linders, G. J., \& De Groot, H. L. 2006. Estimation of the gravity equation in the presence of zero flows. Discussion Paper No. 2006-72/3, Tinbergen Institute, Amsterdam.

Malaysian Rubber Board (Cess) Order 1999. 1999. Retrieved from http://www.lgm.gov.my/LicenseCess/ FormsLicenceCess/3.3.3MalaysianRubberBoard_Cess_ Order1999.pdf

Malaysian Rubber Board (Cess) Order 2009. (2009). Retrieved from http://www.lgm.gov.my/LicenseCess/ FormsLicenceCess/MRBCESSORDER2009.pdf

Malaysian Rubber Export Promotion Council (MREPC). 2015. The Industry. Retrieved 2015, from http://www. mrepc.com/industry/industry.php

Malaysian Rubber Export Promotion Council (MREPC). 2012. Stretch: Rubber Products SMEs: Primed for Growth. (Vol. 6(1)). Kuala Lumpur. MREPC

Malaysian Rubber Export Promotion Council (MREPC). 2013. Stretch: Ministerial Mission to Myanmar. (Vol. 7(2)). Kuala Lumpur. MREPC
Malaysian Rubber Export Promotion Council (MREPC). 2014. Stretch: Bringing Rubber Products to Life. (Vol. 8(2)). Kuala Lumpur. MREPC

Malaysian Rubber Export Promotion Council (MREPC). 2016. Stretch: Glove Donation Programme in India. (Vol. 9). Kuala Lumpur. MREPC

Mayer, T., \& Zignago, S. 2011. Notes on CEPII's distances measures: The GeoDist database.

Ministry of International Trade and Industry. 2020. Malaysia External Trade Statistics, Kuala Lumpur (Malaysia).

Narayan, S., \& Nguyen, T. T. 2016. Does the trade gravity model depend on trading partners? Some evidence from Vietnam and her 54 trading partners. International Review of Economics \& Finance 41: 220-237.

Need for MREPC Funding Review.1999. Business Times Retrieved from https://search.proquest.com

Nothdurft, W. E. 1992. Going global: How Europe Helps Small Firms Export. Washington D.C. Brookings Institution Press.

Ong, E. L. 2001. Recent Advances in the Malaysia's Glove lndustry in Meeting Today's Healthcare Challenges. Latex 2001, 37-50.

Ong, E. L. 2014. MRPMA Future Directions [PowerPoint slides]. Retrieved from http://www.mrepc.com/ seminarpaper/pdf/2105935495.pdf.

Onunkwo, I. M., \& Epperson, J. E. 2000. Export demand for US pecans: Impacts of US export promotion programs. Agribusiness 16(2): 253-265.

Ooi, T. C. 2005. Chin: Cabinet to study request. Business Times Retrieved from https://search.proquest.com

Plan For Worldwide Office To Promote M'sian Rubber Products. 1998. Utusan Malaysia. Retrieved from http://ww1.utusan.com.my/utusan/info. asp? $y=1998$ andd $t=1226$ andpub=Utusan_Expres sandsec $=$ Businessandpg $=$ bs_02.htm

Reubens, E. P.1956. Commodity Trade, Export Taxes and Economic Development. Political Science Quarterly 71(1): 42-70.

Repetto, R. 1972. Optimal export taxes in the short and long run, and an application to Pakistan's jute export policy. The Quarterly Journal of Economics 396-406.

Rose, A. K. 2007. The foreign service and foreign trade: embassies as export promotion. The World Economy 30(1): 22-38.

Rubber products makers want cess removed. 1996. Business Times Retrieved from http://ezproxy.um.edu.my/ docview $/ 266756004$ ?accountid $=28930$

Rubberex Corporation Berhad .2017. Rubberex Corporation Berhad Annual Report. Retrieved from http://disclosure.bursamalaysia.com/FileAccess/ apbursaweb/download?id=179923 andname=EA_DS_ ATTACHMENTS

Solleder, O. 2013. Trade effects of export taxes (No. 08/2013). Graduate Institute of International and Development Studies Working Paper.

Supermax Corporation Berhad. 2017. Supermax Corporation Berhad Annual Report. Retrieved June 26, 2017, from http://disclosure.bursamalaysia.com/FileAccess/ apbursaweb/download?id=17 7416andname=EA_DS ATTA CHMENTS

Sundaram, J. K., \& Wee, C. H. 2013. Malaysia@ 50: Economic Development, Distribution, Disparities. World Scientific. 
Tinbergen, J. 1962. Shaping the world economy; suggestions for an international economic policy. Books (Jan Tinbergen).

Top Glove Corporation Bhd. 2017. Top Glove Corporation Bhd Annual Report. Retrieved from http://disclosure.bursamalaysia.com/FileAccess/ apbursaweb/download?id=177723andname=EA_DS ATTACHMENTS

UNAIDS. 2019. UNAIDS Info. Retrieved from http://aidsinfo. unaids.org/

UN Comtrade. 2015. UN Comtrade Database. Retrieved from http://comtrade.un.org/

Unit signs pact to buy US condom maker for \$1.3m. 2016. Nikkei Asian Review Retrieved from https://asia.nikkei. com/Business/AC/Unit-signs-pact-to-buy-US-condommaker-for- $1.3 \mathrm{~m}$

World Bank. World Development Indicators. Retrieved from http://data.worldbank.org/data-catalog /worlddevelopment-indicators

Yip, E. 2004. Consideration of barrier protection and latex protein allergy in the evaluation of medical gloves. Journal of Infusion Nursing 27(4): 227-231.

Yip, E. 2015. Comments to the Joint Committee on Public Health Commonwealth of Connecticut on House Bill 05347 Regarding the Use of Latex Gloves in Food Businesses. Speech presented in Connecticut, United States.
Yip, E. 2017. Comments to the Joint Committee on Public Health of State of Connecticut on Senate Bill 901 Regarding the Recommendation of the Public Health to Adopt a Model Food Code - Concerning the Use of Latex Gloves in Food Businesses. Speech presented in Connecticut, United States.

Lee Siu Ming*

Economics Section, School of Distance Education,

Universiti Sains Malaysia

11700 Penang, MALAYSIA.

E-mail: leesiuming123@gmail.com

Radziah Adam

Economics Section, School of Distance Education,

Universiti Sains Malaysia

11700 Penang, MALAYSIA.

E-mail: radziah_adam@usm.my

Ku’ Azam Tuan Lonik

Economics Section, School of Distance Education,

Universiti Sains Malaysia

11700 Penang, MALAYSIA.

E-mail: kuadzam@usm.my

*Corresponding author 